\title{
FIRE-CRACKER INJURY TO THE EYES IN HONG KONG*
}

\author{
BY \\ RORY TSANG-YUI LEE \\ Government Eye Clinic, Hong Kong
}

THE colony of Hong Kong occupies a land area of $398 \frac{1}{4}$ square miles. The total population at end of 1964 was estimated to be $3,739,900,85$ per cent. being concentrated in the urban areas of Hong Kong Island and Kowloon. On the basis of language and place of origin about 98 per cent. could be described as Chinese. Thus Chinese custom and traditions predominate in Hong Kong. One such custom is to discharge fire-crackers during the Chinese New Year. From 1960 to 1965, a period of 6 years, 262 cases of fire-cracker injury to the eyes were recorded at Government Clinics.

\section{Analysis of Cases}

Age and Sex (Table I and Figure, opposite).-Most of the victims belonged to the 5 to 20-year age group, and injury in males far exceeded that in females (207 males to 55 females). The injuries were nearly all uniocular.

TABLE I

Age, Sex, and Numbers of Patients

\begin{tabular}{|c|c|c|c|c|c|c|c|c|c|c|c|c|c|c|c|c|c|c|}
\hline \multicolumn{2}{|c|}{$\begin{array}{c}\text { Age Group } \\
\text { (yrs) }\end{array}$} & $\begin{array}{c}1 \\
\text { to } \\
4\end{array}$ & $\begin{array}{c}5 \\
\text { to } \\
9\end{array}$ & $\begin{array}{l}10 \\
\text { to } \\
14\end{array}$ & $\begin{array}{l}15 \\
\text { to } \\
19\end{array}$ & $\begin{array}{l}20 \\
\text { to } \\
24\end{array}$ & $\begin{array}{l}25 \\
\text { to } \\
29\end{array}$ & $\begin{array}{l}30 \\
\text { to } \\
34\end{array}$ & $\begin{array}{l}35 \\
\text { to } \\
39\end{array}$ & $\begin{array}{l}40 \\
\text { to } \\
44\end{array}$ & $\begin{array}{l}45 \\
\text { to } \\
49\end{array}$ & $\begin{array}{l}50 \\
\text { to } \\
54\end{array}$ & $\begin{array}{l}55 \\
\text { to } \\
59\end{array}$ & $\begin{array}{l}60 \\
\text { to } \\
64\end{array}$ & $\begin{array}{l}65 \\
\text { to } \\
69\end{array}$ & $\begin{array}{l}70 \\
\text { to } \\
74\end{array}$ & $\begin{array}{l}75 \\
\text { to } \\
79\end{array}$ & $\begin{array}{l}\text { Total } \\
\text { Cases }\end{array}$ \\
\hline \multirow{2}{*}{ Sex } & Male & 14 & 71 & 49 & 19 & 9 & 10 & 4 & 10 & 14 & 3 & 1 & - & 1 & - & 1 & 1 & 207 \\
\hline & Female & 9 & 12 & 13 & 5 & - & 2 & 3 & 2 & 1 & 5 & 1 & 1 & - & - & 1 & - & 55 \\
\hline
\end{tabular}

Mode of Injury.-During the Chinese New Year celebrations, lighted fire-crackers are thrown about aimlessly from all places and in all directions. Most of the patients stated that they had been injured by the carelessness of others. Only a very small group admitted injuring themselves while discharging fire-crackers.

Clinical Findings.-These are given in detail in Table II (opposite).

\section{Investigation and Treatment}

The orbit was $x$-rayed in all cases of penetrating injury, hyphaema, and cataract to exclude radio-opaque intra-ocular foreign body. The result was negative in all cases.

* Received for publication June 3, 1965. 


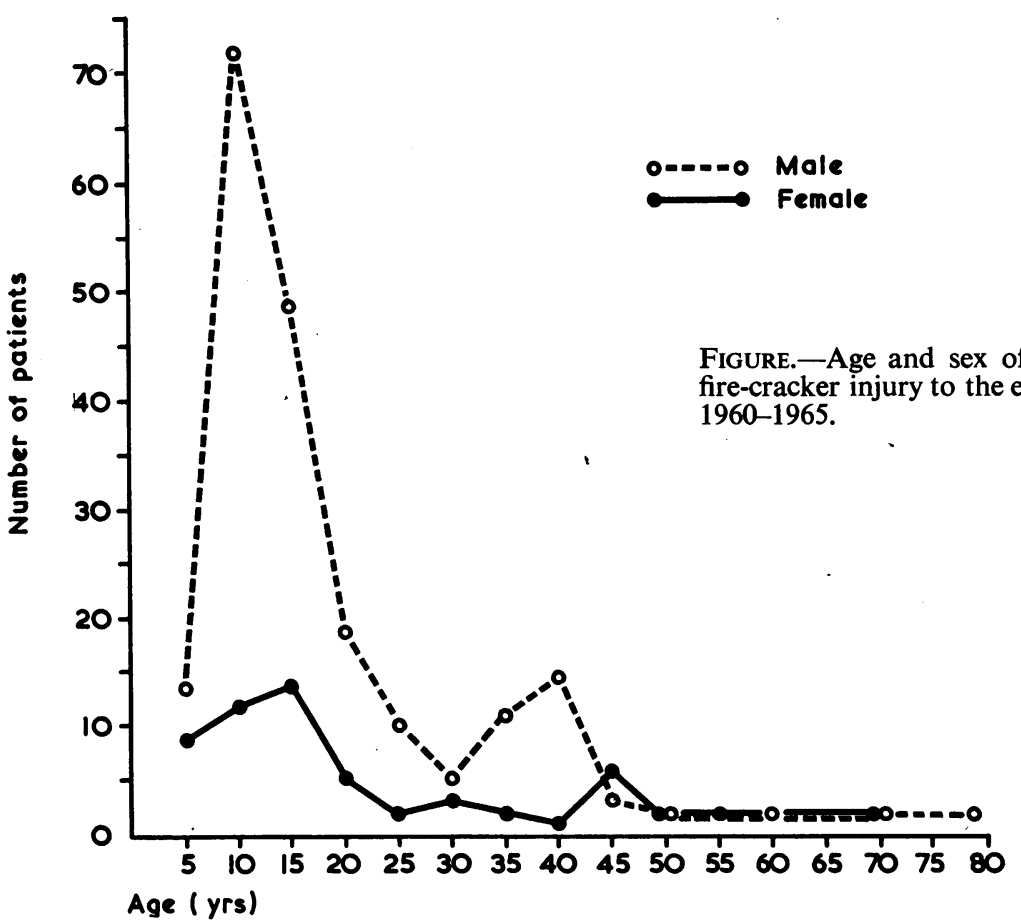

TABle II

Clinical Findings, BY Year

\begin{tabular}{|c|c|c|c|c|c|c|c|c|c|}
\hline \multirow{2}{*}{$\begin{array}{l}\text { Type of } \\
\text { Injury }\end{array}$} & \multirow{2}{*}{ Clinical Findings } & \multicolumn{6}{|c|}{ Year } & \multicolumn{2}{|c|}{ Total } \\
\hline & & 1960 & 1961 & 1962 & 1963 & 1964 & 1965 & No. & Per cent. \\
\hline Penetrating & Laceration of Cornea and Sclera & 3 & 3 & - & - & 1 & 4 & 11 & $4 \cdot 21$ \\
\hline \multirow{12}{*}{$\begin{array}{c}\text { Non- } \\
\text { Penetrating }\end{array}$} & Burn and Abrasion of Lid & 8 & 6 & 5 & 4 & 8 & 7 & 38 & $14 \cdot 56$ \\
\hline & Traumatic Conjunctivitis & 8 & 1 & 5 & 5 & 4 & 5 & 28 & $10 \cdot 73$ \\
\hline & Laceration of Conjunctiva & - & - & 2 & 1 & - & 4 & 7 & $2 \cdot 68$ \\
\hline & Subconjunctival Ecchymosis & - & 3 & 2 & 3 & 4 & 2 & 14 & $5 \cdot 37$ \\
\hline & Corneal Abrasion and Ulcer & 8 & 12 & 12 & 12 & 9 & 10 & 63 & $24 \cdot 14$ \\
\hline & Corneal Foreign Bodies & 2 & 5 & 2 & 2 & 4 & 1 & 16 & $6 \cdot 13$ \\
\hline & Hyphaema & 9 & 6 & 4 & 6 & 7 & 5 & 37 & $14 \cdot 17$ \\
\hline & Traumatic Mydriasis & - & - & 2 & 1 & 3 & - & 6 & $2 \cdot 30$ \\
\hline & Iridodialysis & 1 & 2 & 1 & - & - & - & 4 & $1 \cdot 53$ \\
\hline & Traumatic Cataract & 1 & 1 & 5 & 5 & 4 & 8 & 24 & $8 \cdot 82$ \\
\hline & Vitreous Haemorrhage & 1 & - & 2 & - & 2 & 1 & 6 & $2 \cdot 30$ \\
\hline & Retinal Oedema & - & 1 & 1 & 1 & 1 & 4 & 8 & 3.06 \\
\hline Total & & 41 & 40 & 43 & 40 & 47 & 51 & 262 & 100 \\
\hline
\end{tabular}


Surgery.-This consisted of repair of laceration of conjunctiva, cornea, and sclera, and removal of corneal foreign body.

Topical Therapy.-This consisted of prevention of infection with antibiotic eye-drops and ointment, mydriatics for corneal lesions, and enzymes for haemorrhage. Topical steroids were used in some cases to prevent symblepharon formation.

Systemic Therapy.-This consisted of vitamins, antibiotics for controlling infection, and carbonic anhydrase inhibitor (Diamox) to lower the intra-ocular pressure where necessary.

\section{Results}

The lesions involving lids, conjunctiva, and cornea (63.61 per cent.) healed well and left no visual impairment after treatment. Two cases of mild symblepharon occurred involving the lower lid. These were in the groups for which follow-up was poor: presumably the patients were cured after the first treatment.

Eight patients with hyphaema had permanent damage to one eye. The results are shown in Table III.

TABLE III

RESUlTS AFTER HYPHAEMA

\begin{tabular}{c|c|c|c|c|c}
\hline Results & No Follow-up & Well & Iridodialysis & Traumatic Cataract & $\begin{array}{c}\text { Optic Atrophy and } \\
\text { Retinal Degeneration }\end{array}$ \\
\hline No. of Cases & $\begin{array}{c}16 \\
\text { (assumed well) }\end{array}$ & 9 & 4 & 5 & 3 \\
\hline
\end{tabular}

Traumatic mydriasis, iridodialysis, vitreous haemorrhage, and retinal oedema (9.19 per cent.) quietened uneventfully after treatment without damage to the sight.

Among the cases of non-penetrating injury were 24 cases of traumatic cataract (8.82 per cent.), in which vision was severely impaired.

Of eleven patients ( 4.21 per cent.) with penetrating injury, only four regained a reasonable degree of visual acuity; the rest ended in traumatic cataract (4 cases), and atrophy of the globe ( 3 cases). No case of sympathetic ophthalmitis was observed.

In the end 39 out of 262 cases had permanent damage to sight (14.88 per cent.).

\section{Prevention}

Despite the ever-increasing population, the incidence of fire-cracker injury has remained more or less the same (Table IV), a fact that must be credited to the

TABle IV

INCIDENCE OF EYE INJURY, BY YEAR

\begin{tabular}{c|c|c|c}
\hline Year & Estimated Mid-year Population & No. of Injuries & Incidence per 10,000 \\
\hline 1960 & $2,981,000$ & 41 & $1 \cdot 40$ \\
1961 & $3,177,700$ & 40 & $1 \cdot 26$ \\
1962 & $3,400,000$ & 43 & $1 \cdot 26$ \\
1963 & $3,592,100$ & 40 & $1 \cdot 12$ \\
1964 & $3,692,200$ & 47 & $1 \cdot 30$ \\
1965 & $3,739,900$ (end of 1964) & 51 & $1 \cdot 33$ \\
\hline
\end{tabular}


Secretary for Chinese Affairs, who has taken the following preventive measures:

1. Posters,

2. Broadcast talks in Chinese and English,

3. Newspaper articles;

4. Police action prosecuting the offenders,

5. Shortening the permitted hours of discharging fire-crackers: 41 hours in 1960, 1961, 1962, and 1963; 15 hours in 1964; and 17 hours in 1965.

\section{Summary}

262 cases of fire-cracker injury to the eyes are reported and analysed. The injuries are usually uniocular. About one-sixth of them caused blindness due to traumatic cataract, atrophia bulbi, optic atrophy, and retinopathy.

I am very much indebted to my colleagues for their help and to the Hon. Director of Medical and Hospital Services, Medical and Health Department, Hong Kong, for permission to publish this article.

\section{BIBLIOGRAPHY}

Duke-Elder, S. (1954). "Text-book of Ophthalmology”, vol. 6, pp. 5751-6123. Kimpton, London. (1959). "Parsons' Diseases of The Eye", 13th ed., p. 384. Churchill, London.

Hong Kong (1965). "Hong Kong Report for The Year 1964”, p. 241. Government Office, Hong Kong (H.M.S.O., London).

Trevor-Roper, P. D. (1962). “Ophthalmology”, 2nd ed., p. 403. Lloyd-Luke (Medical Books), London. Vaughan, D., CooK, R., and Asbury, T. (1962). "General Ophthalmology", 3rd ed., p. $253 . \quad$ Lange, Los Altos, California. 